\title{
Pengaruh Komitmen dan Peran Pengelola Keuangan Terhadap Kinerja (Studi pada Pengelola Keuangan SKPK di Pemerintahan Kabupaten Aceh Timur)
}

\author{
Muhammad Jamil ${ }^{1 *}$, Teuku Muana Refi ${ }^{2}$ \\ 1,2 Program Studi Keuangan Dan Perbankan, Akademi Keuangan Perbankan \\ Nusantara, Kabupaten Aceh Timur, Provinsi Aceh, Indonesia.
}

\begin{abstract}
Abstrak. Penelitian ini bertujuan untuk memutuskan dampak tanggung jawab dan peran direksi terhadap pelaksanaan. Pemeriksaan ini dipimpin oleh SKPK di lingkungan Pemerintah Daerah Aceh Timur. Sampel data pemeriksaan ini adalah 49 pejabat administrasi keuangan eselon IV yang diambil dengan strategi pemeriksaan purposive. Informasi dikumpulkan dengan menggunakan survei dan kemudian informasi tersebut diperiksa menggunakan berbagai teknik relaps langsung. Investigasi ini melacak bahwa tanggung jawab kepala keuangan dan bagian direksi bersama-sama mempengarubi kinerja pengawas keuangan. Tanggung jawab pengawas kenangan secara positif mempengarubi pameran direktur keuangan. Bagian dari pengawas keuangan tidak mempengarubi pameran direktur keuangan.
\end{abstract}

Kata kunci: Kinerja Pengelola Kenangan; Komitmen Pengelola Kenangan; Peran Pengelola Kenangan.

Abstract. This study aims to determine the impact of responsibilities and roles on implementation. This examination was led by the SKPK within the East Aceh Regional Government. The sample of this audit data is 49 echelon IV financial administration officials who were taken for strategic audit purposes. Information is collected using surveys and then the information is checked using various direct relapse techniques. This investigation traces that the responsibilities of the chief financial officer and the department together affect the performance of the financial supervisor. The responsibilities of the financial supervisor positively affect the finance director. Part of the financial supervisor does not affect the finance director.

Keywords: Financial Manager Performance; Financial Management Commitment; Role of Financial Manager.

*Author. Email: muhammadjamil@akubanknusantara.ac.id ${ }^{1 *}$. teukumuanarefi@amikindonesia.ac.id ${ }^{2}$. 


\section{Pendahuluan}

Badan pemeriksa keuangan memberikan opini wajar tanpa pengecualiaan terhadap Laporan Keuangan Pemerintah Daerah Kabupaten Aceh Timur selama periode 2011 ssampai dengan tahun 2019. Opini Opini Wajar Tanpa Pengecualian (WTP) atau Unqualified Opinion yang diperolah oleh pemerintah kabupaten Aceh Timur disambut baik oleh masyarakat. Namun ada juga yang berpendapat negatif mengingat pelayanan yang masih lemah dalam hal informasi publik. Ada beberapa Lembaga Swadaya Masyarakat (LSM) yang menyoroti kinerja pemerintah Kabupaten Aceh Timur dan menyatakan belum layak untuk mendapatkan prediket WTP. Kinerja pemerintah daerah salah satu cerminan dari kinerja pengelola keuangah daerah pada Pemerintah Kabupaten Aceh Timur. Lemahnya pelayanan publik salah satunya disebabkan oleh kinerja pengelola keuangan daerah pada pemerintah Kabupaten Aceh Timur masih rendah. Pengelola keuangan daerah belum mampu untuk melaksankan dan menyelesaikan tugasnya sesuai dengan peraturan yang berlaku. Kinerja merupakan hasil pekerjaan yang mempunyai hubungan kuat dengan tujuan strategis organisasi, kepuasan konsumen, dan memberikan kontribusi pada ekonomi (Maria Mega Ayu Novrilia, Nina Widowati, 2014).

Pengelola keuangan daerah banyak yang memiliki pandangan bahwa peraturan perundang-undangan yang ditetapkan oleh pemerintah pusat terkesan dibuat tergesa gesa dan tidak ada dengan tingkat operasional yang lebih rendah. Pandangan seperti ini dapat mengakibatkan pelayanan publik dalam hal keuangan menjadi rendah. Persepsi bahwa setiap tahun selalu ada perubahan peraturan tentang pengelolaan keuangan daerah sehingga pengelola keungan enggan untuk memahami aturan yang terbaru. Selanjutnya pengelola keuangan daerah yang tidak transparan dan akuntabel akan mengakibatkan terhambatnya kegiatan yang akan dilaksanakan maupun yang sedang berlangsung. Pengelola keuangan daerah yang tidak mampu melaksanakan sesuai dengan aturan yang telah ditetapkan salah satunya akan berdampak pada menurunya produktifitas pegawai.

\section{Literature Review}

Komitmen dari karyawan merupakan sesuatu yang penting. Karena dampaknya antara lain terhadap keterlambatan, ketidakhadiran, keinginan untuk pindah kerja, dan perputaran tenaga kerja (Baihaqi, 2012). Komitmen organisasi merupakan dimensi positif dari sikap karyawan yang berhubungan dengan kinerja dalam komitmen organisasi juga didefinisikan sebagai tingkat perasaan dan kepercayaan terhadap organisasi tempat mereka bekerja (Wulandari, 2016). Kinerja Pimpinan merupakan kinerja individu dalam kegiatankegiatan manajerial seperti dari proses perencanaan, investigasi, koordinasi, evaluasi, supervisi, pengaturan staf (staffing), negosiasi dan representasi. Kinerja manajerial satuan kerja perangkat daerah adalah gambaran pencapaian pelaksanaan suatu kegiatan atau program dalammewujudkan sasaran, tujuan, misi dan visi organisasi (Diyanto et al., 2015).

\section{Pengaruh Pengelolaan Keuangan Daerah Terhadap Kinerja Ekonomi Daerah di} Kabupaten Kerinci, Penelitian ini mengambil lokasi di Kantor Badan Pengelolaan Keuangan dan Pendapatan Daerah (BPKPD), dengan rumusan masalah penelitian. Penelitiaan ini menggunakan pendekatan kuantitatif dimana data diperoleh melalui kuesioner dilapangan kepada 42 orang responden yang mengacu kepada indikator penelitian variabel (X) Pengelolaan Keuangan Daerah terhadap variabel (Y) Kinerja Ekonomi Daerah. Data yang diperoleh dilapangan dianalisis berdasarkan rumus, Regresi Linear Sederhana untuk melihat pengaruh antara variabel $\mathrm{X}$ terhadap variabel Y. KD (Koefisien Determinasi) untuk melihat besarnya pengaruh antara variabel $\mathrm{X}$ terhadap variabel $\mathrm{Y}$. Dari hasil penelitian diketahui bahwa Pengelolaan Keuangan Daerah berpengaruh terhadap Kinerja Ekonomi Daerah sebesar 26,7\%. Untuk itu penulis menyarankan agar Pengelolaan Keuangan Daerah dapat ditingkatkan agar Kinerja Ekonomi Daerah semakin efektif dan efisien (Mone dkk, 2013).

Penelitian Analisis Faktor-faktor yang Mempengaruhi Kinerja Pegawai pada Dinas Pendapatan, Pengelolaan Keuangan dan Aset (DPPKA) Kota Bengkulu, Tujuan penelitian 
untuk mengetahui faktor yang paling dominan mempengaruhi kinerja pegawai pada DinasPendapatan, Pengelolaan Keuangan dan Aset (DPPKA) Kota Bengkulu. Metode pengumpulan data yang digunakan dalam penelitian adalah metode kuisioner, sedangkan metode analisis menggunakan skalalikert, danrating scale. Dari lima faktor yang mempengaruhi kinerja pegawai pada Dinas Pendapatan, Pengelolaan Keuangan dan Aset (DPPKA) Kota Bengkulu, empat factor yaitu personal factors, team factors, system factor, dan contextual factors mendapat persepsi dari responden dengan criteria setuju, artinya keempat factor tersebut mempengaruhi kinerja pegawai. Sedangkan satu factor yaitu leadership factors mendapat persepsi sangat setuju, artinya pemimpin sangat mempengaruhi kinerja pegawai. Faktor yang paling dominan mempengaruhi kinerja pegawai pada Dinas Pendapatan, Pengelolaan Keuangan dan Aset (DPPKA) Kota Bengkulu adalah leadership factors, karena mempunyai peranan penting dalam mengayomi, mendukung (Sukarno \& Syaichu, 2006).

\section{Kerangka Penelitian dan Pengembangan Hipotesis}

\section{Pengaruh Komitmen terhadap Kinerja.}

Komitmen organisasional didefinisikan sebagai suatu keadaan dimana karyawan mengkaitkan dirinya pada organisasi tertentu dan sasaransasarannya, dan berharap mempertahankan keanggotaannya dalam organisasi tersebut (Shalahuddin, 2018). Sebuah organisasi memerlukan manusia sebagai sumber daya pendukung utama untuk mencapai tujuan yang telah ditetapkan. Sumber daya manusia yang berkualitas akan turut memajukan organisasi sebagai suatu wadah peningkatan produktivitas kerja (Mone dkk, 2013). Kinerja adalah pencapaian suatu hasil yang dikarakteristikan dengan keahlian tugas seseorang ataupun kelompok atas dasar tujuan yang telah ditetapkan (Ranty Sapitri, 2016). Para pengelola keuangan yang menunjukkan tanggung jawab ingin memberikan tenaga dan tugas yang lebih mendalam agar dapat meningkatkan presentasinya dalam administrasi keuangan. Tanggung jawab otoritatif adalah suatu kondisi di mana pekerja sangat tertarik pada tujuan, kualitas, dan metode untuk organisasi. Tanggung jawab yang signifikan lebih menonjol dari pada partisipasi formal, karena itu hanyalah watak mencintai organisasi dan keinginannya untuk menginvestasikan tingkat energi yang lebih tinggi mengingat kepedulian yang sah terhadap organisasi untuk mencapai tujuan.

\section{Pengaruh Komitmen dan Peran Pengelola Kenangan Terbadap Knerja}

Peran manajer pengelolaan anggaran ialah tindakan yang dilakukan oleh pejabat pengelolaan anggaran/kepala instansi dengan menggunakan pengaruhnya untuk memotivasi dan mendorong bawahan untuk mencapai tujuan organisasi. Peran menunjukkan partisipasi seorang dalam mewujudkan tujuan organisasi (Alhayati, 2013). Seorang pimpinan yang memberikan kepercayaan dan kesempatan pada bawahannya untuk berpartisipasi dalam setiap kegiatan dapat menimbulkan dan memberikan rasa tanggung jawab serta mendorong kreativitas para bawahan untuk bekerja lebih giat lagi dalam mencapai tujuan, sehingga kinerja organisasi akan lebih tinggi lagi. Komitmen organisasional menurut Mathis dan Jackson memberikan definisi "organizational commitment is the degree to which employees believe in and accept organizational goals an desire to remain with the organizational'. Komitmen organisasional adalah derajat yang mana karyawan percaya dan menerima tujuan-tujuan organisasi dan tetap akan tinggal atau tidak akan meninggalkan organisasi. Komitmen organisasi yang dikemukakan oleh Mowday et. al ini memiliki ciri-ciri, yaitu; 1) Belief yang kuat serta penerimaan terhadap tujuan dan nilai organisasi, 2) Kesiapan untuk bekerja keras, dan 3) Keinginan yang kuat untuk bertahan dalam organisasi (Alokasi et al., 2013).

Dengan manajer yang memiliki pekerjaan ini, ia mendesak pengawas keuangan untuk menyelesaikan tujuan yang ditetapkan oleh asosiasi pemerintah terdekat. Jadi dengan bagian dari pengeluaran para pengawas eksekutif, adalah mungkin untuk mencapai pelaksanaan dan komponen pemerintah yang baik dan sukses. 


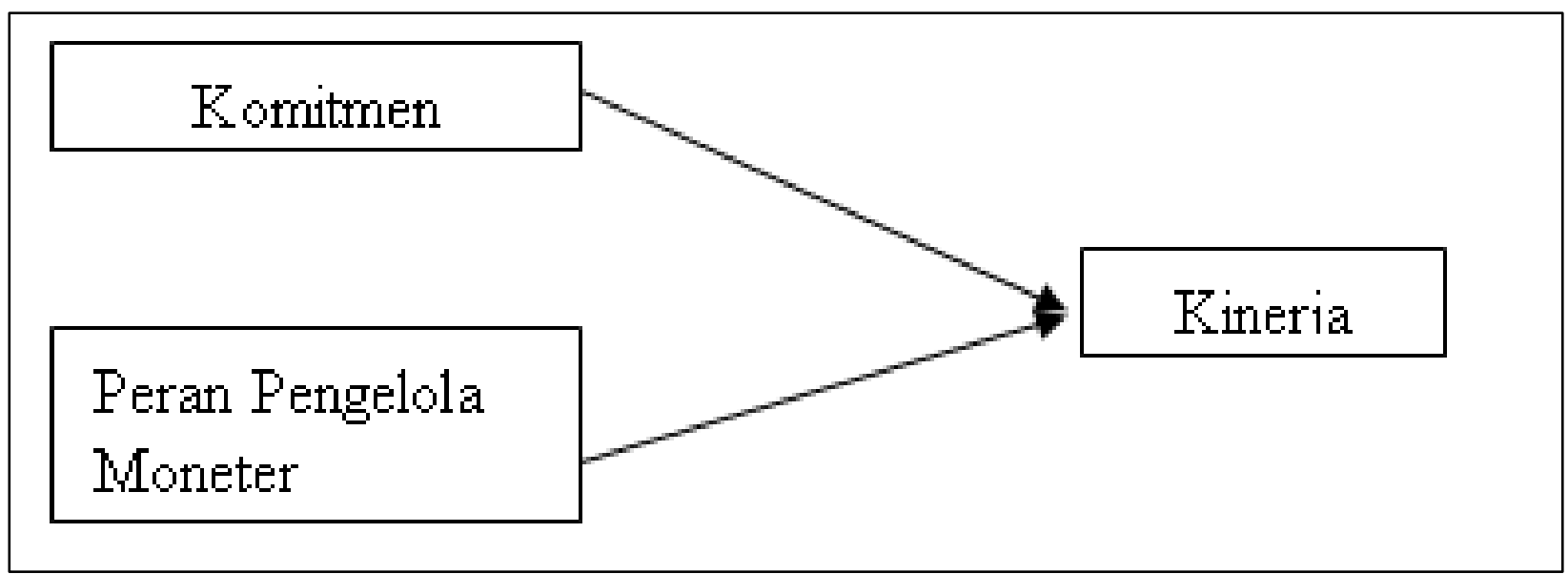

Gambar 1. Kerangka Pemikiran Penelitian

Menyinggung sistem eksplorasi yang digambarkan di atas, penelitian ini menunjukkan bahwa ada hubungan positif yang sangat besar antara tanggung jawab dan tugas pengawas keuangan dengan penunjukan direktur keuangan di SKPK di Pemerintah Daerah Aceh Timur.

\section{Metodologi Penelitian}

\section{Lokasi, Objek dan Ruang Lingkup Penelitian}

Sesuai dengan rumusan masalah diatas maka lokasi penelitian ini dilakukan di SKPK di Kabupaten Aceh Timur. Sedangkan objek penelitian ini di fokuskan pada pejabat pengelola keuangan eselon IV. Komitmen dalam penelitian in adalah rasa ketertarikan pejabat pengelola keuangan eselon IV untuk tetap berada di organisasi tempat bertugas. Selanjutnya peran pengelola keuangan adalah sejauh mana pean yang diberikan oleh pimpinan dalam mengelola keuangan.

\section{Populasi dan Penarikan Sampel}

Jumlah populasi dalam penelitian ini adalah seluruh pejabat eselon IV pada satuan kerja perangkat daerah di lingkungan DPRD Kabupaten Aceh Timur yang ditemukan sebanyak 626 orang. Contoh dalam pemeriksaan ini adalah pejabat eselon IV di SKPK Pemerintah Rezim Aceh Timur sebanyak 49 orang. Pemilihan sampel ini tergantung pada strategi pemeriksaan purposive, dimana sampel yang dipilih adalah pejabat eselon IV yang mengawasi dana di SKPK Pemerintah Aceh Timur.

\section{Teknik Pengumpulan Data dan Skala Pengukuran}

Informasi yang digunakan dalam penelitian ini adalah informasi penting, prosedur pengumpulan informasi yang digunakan dalam pemeriksaan ini adalah penyelidikan yang menggunakan daftar yang diberikan kepada responden untuk memperoleh informasi. Informasi pemeriksaan ini dikumpulkan dengan cara memberikan survei langsung kepada responden, serta pengambilan langsung dari responden yang ditunjukkan dengan jaminan. Responden didekati untuk melengkapi survei yang berisi pernyataan-pernyataan yang akan dipilih oleh responden sebagai salah satu jenis penilaian.

\section{Operasional Variabel}

Mengingat sistem yang telah ditentukan sebelumnya, dua faktor yang harus diperkirakan dipilih. Kedua faktor tersebut secara wajar dapat dipisahkan menjadi faktor bebas (faktor otonom), khususnya variabel tanggung jawab administrasi keuangan teritorial (diperkirakan dengan tiga indikator) dan variabel pekerjaan direktur keuangan (diperkirakan dengan tujuh indikator). Sedangkan variabel terikatnya adalah kinerja (diperkirakan dengan tiga indikator).

Faktor-faktor dalam penelitian ini diperkirakan melalui instrumen yang telah dibuat dan digunakan oleh para ilmuwan masa lalu. Faktor operasional diisolasi menjadi dua kelompok, khususnya variabel terikat (dependent variable) dan faktor bebas (variabel otonom). Definisi dan petunjuk dari setiap faktor dijelaskan pada tabel 1 berikut. 
Tabel 1. Operasional Variabel

\begin{tabular}{|c|c|c|c|c|c|}
\hline No & Variabel & Definisi & Indikator & Item Kurisioner & Sumber \\
\hline 1. & Kinerja & $\begin{array}{l}\text { Suatu prestasi yang dicapai } \\
\text { oleh pegawai } \\
\text { pemerintahan dalam } \\
\text { melaksanakan pelayanan } \\
\text { kepadamasyarakat } \\
\text { menyangkut dengan } \\
\text { keuangan daerah. }\end{array}$ & 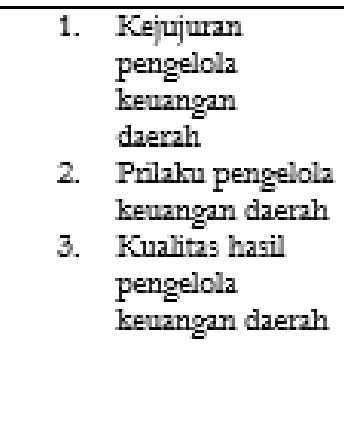 & $\begin{array}{l}\text { 1.Indikator } 1 \\
\text { untuk item } \\
\text { kuigioner no. } 1 \\
\text { dan } 2 \\
\text { 2. Indikator } 2 \\
\text { untuk item } \\
\text { kuigioner no. } 3 \\
\text { dan } 4 \\
\text { 3. Indikator } 3 \\
\text { untuk item } \\
\text { kuigioner } 5 \text { dan } \\
6\end{array}$ & $\begin{array}{l}\text { Dalimunthe } \\
2011\end{array}$ \\
\hline 2. & Komitmen & $\begin{array}{l}\text { Pengakuan seutuhnya yang } \\
\text { tercemin dalam tindakan } \\
\text { atau periaku dalam } \\
\text { pengelolaan semua hak } \\
\text { dan kewajiban daerah yang } \\
\text { dapat dinilai dengan uang } \\
\text { dan segala sesuatu berupa } \\
\text { uang dan barang yang } \\
\text { dapat dijadikan milik } \\
\text { daerah yang berhubungan } \\
\text { dengan pelaksanaan hak } \\
\text { dan kewajiban tersebut. } \\
\text { Mone.dkk, 2013) }\end{array}$ & $\begin{array}{ll}\text { 1. } & \begin{array}{l}\text { Komitmen } \\
\text { efektif }\end{array} \\
\text { 2. } & \begin{array}{l}\text { Komitmen } \\
\text { nomatife }\end{array} \\
\text { 3. } & \begin{array}{l}\text { Komitmen } \\
\text { kontinyu }\end{array}\end{array}$ & $\begin{array}{l}\text { 1.Indikator } 1 \\
\text { untuk item } \\
\text { kuisioner no. } 1 \\
\text { dan } 2 \\
\text { 2. Indikator } 2 \\
\text { untuk item } \\
\text { kuisioner no. } 3 \\
\text { dan } 4 \\
\text { 3. Indikator } 3 \\
\text { untuk item } \\
\text { huigioner } 5 \text { dan } \\
6\end{array}$ & $\begin{array}{l}\text { Dalimunthe } \\
2011\end{array}$ \\
\hline 3. & $\begin{array}{l}\text { Peran } \\
\text { pengelola } \\
\text { keuangan }\end{array}$ & $\begin{array}{lr}\text { Partisipasi } & \text { dalam } \\
\text { mewujudkan tujuan } \\
\text { organisasi demi } \\
\text { tercapainya mekanisme } \\
\text { penyelenggaraan } \\
\text { pemerintahan yang efisien } \\
\text { dan efektif }\end{array}$ & $\begin{array}{l}\text { 1. Tujuan dasar dan } \\
\text { sasaran } \\
\text { organisasi } \\
\text { 2. Menyusun } \\
\text { program dan } \\
\text { kegiatan } \\
\text { 3. Menentukan } \\
\text { alokasi sumber } \\
\text { daya ekonomi } \\
\text { 4. Membandingkan } \\
\text { angggaran dan } \\
\text { realisasi } \\
\text { 5. Mencatat } \\
\text { pendapatan dan } \\
\text { belanja } \\
\text { 6. Melaporkan } \\
\text { pendapatan dan } \\
\text { belanja } \\
\text { 7. Menganalisis bila } \\
\text { terjadi perbedaan }\end{array}$ & $\begin{array}{l}\text { 1.Indikator } 1 \\
\text { untuk item } \\
\text { kuisioner no.1 } \\
\text { 2. Indikator } 2 \\
\text { untuk item } \\
\text { kuisioner no. } 2 \\
\text { 3. Indikator } 3 \\
\text { untuk item } \\
\text { kuigioner } 3 \\
\text { 4. Indikator } 4 \\
\text { untuk item } \\
\text { huisioner no. } 4 \\
\text { 5. Indikator } 5 \\
\text { untuk item } \\
\text { kuigioner no.5 } \\
\text { 6. Indikator } 6 \\
\text { untuk item } \\
\text { huisioner no. } 6 \\
7 . \text { Indikator } 7 \\
\text { untuk item no.7 }\end{array}$ & Putri $(2010)$ \\
\hline
\end{tabular}

\section{Peralatan Analisis Data}

Penyelidikan informasi dilakukan dengan menggunakan berbagai kekambuhan langsung yang berencana untuk memutuskan hubungan dan dampak tanggung jawab dan peran direktur keuangan pada eksekusi. Informasi yang didapat akan dikaji secara terukur dengan menggunakan program SPSS (Statistical Package for Social Science). Model ilmiah yang digunakan adalah regresi linear berganda, dengan model persamaan:

$$
\mathrm{Y}=\mathrm{a}+\mathrm{b}_{1} \mathrm{X}_{1}+\mathrm{b} 2 \mathrm{X}_{2}+\mathrm{e}
$$

$\begin{array}{ll}\mathrm{Y} & : \text { Kinerja } \\ \mathrm{a} & : \text { Konstanta } \\ \mathrm{b} & : \text { Koefesien regresi } \\ \mathrm{X} 1 & : \text { Komitmen } \\ \mathrm{X} 2 & : \text { Peran pengelola keuangan } \\ \mathrm{e} & : \text { Error of estimation. }\end{array}$

\section{Hasil dan Pembahasan}

Eksekusi merupakan prestasi yang dicapai oleh aparatur pemerintah dalam melakukan administrasi ke daerah yang diidentikkan 
dengan uang daerah. Reaksi responden terhadap pelaksanaan menunjukkan bahwa tanggapan responden normal terhadap faktorfaktor tersebut dapat diterima dan mengagumkan.

Selain itu, tanggung jawab dapat diartikan sebagai penegasan total yang dapat dilihat dari kegiatan atau perbuatan dalam segala hak dan komitmen yang dapat dihargai dalam bentuk uang dan segala sesuatu atau produk yang dapat digunakan sebagai milik teritorial yang diidentifikasi dengan pelaksanaan hak dan komitmen tersebut. Reaksi responden menunjukkan bahwa tanggapan responden normal terhadap pernyataan variabel ini tinggi. Tugas kepala keuangan adalah dukungan dalam mengakui tujuan hierarkis untuk pengakuan komponen administrasi yang kompeten dan menarik. Reaksi responden menunjukkan bahwa respons normal terhadap penegasan variabel ini adalah tinggi dan sangat tinggi.

\section{Hasil Pengujian Hipotesis}

Nilai R square adalah 0,109, yang berarti bahwa variabel tanggung jawab administrator keuangan dan pekerjaan kepala keuangan hanya menjelaskan 0,109 atau $10,9 \%$ dari eksekusi direktur keuangan, sedangkan kelebihan $89,1 \%$ dijelaskan oleh berbagai faktor yang dikecualikan dari model eksplorasi ini. Dapat dikatakan bahwa tanggung jawab direktur keuangan dan bagian kepala keuangan hampir tidak berdampak pada kehadiran pengawas keuangan di Wilayah Aceh Timur.

Dampak Tanggung Jawab Bersama Direktur Keuangan dan Sebagian Kepala Keuangan pada Pameran Administrator Keuangan didasarkan bahwa nilai kemungkinan lebih besar dari 0,05 maka $\mathrm{Ha}$ diterima dan $\mathrm{Ho}$ ditolak. Orang mungkin mengatakan bahwa tanggung jawab pengawas keuangan dan bagian dari administrator keuangan bersamasama tidak berdampak pada presentasi direktur keuangan pada tingkat yang sangat besar sebesar 5\%. Meskipun demikian, Ho ditolak dan $\mathrm{Ha}$ diterima ketika menggunakan tingkat kepentingan 10\%. Oleh karena itu, dapat disimpulkan bahwa tanggung jawab pengawas sebesar 5\% dan tugas kepala keuangan bersama-sama tidak berdampak pada presentasi administrator keuangan. Meskipun demikian, pada tingkat kritis 10\%, tanggung jawab direktur keuangan dan pekerjaan administrator keuangan secara bersama-sama mempengaruhi presentasi kepala keuangan.

Pengaruh Tanggung Jawab Direktur Keuangan terhadap Pameran Pengawas Keuangan menunjukkan bahwa variabel Tanggung Jawab Administrator Keuangan adalah 0,039. Ini berarti menoleransi Ha dan menolak Ho, dapat dikatakan bahwa variabel tanggung jawab administrator keuangan secara positif mempengaruhi presentasi kepala keuangan dengan alasan bahwa tingkat kritis lebih rendah dari 0,05. Dapat ditegaskan bahwa tanggung jawab pengawas keuangan adalah kemampuan untuk menyelenggarakan administrasi keuangan sesuai dengan peraturan perundang-undangan. Pelaksanaan administrasi keuangan sesuai pedoman tetap dapat meningkatkan pelaksanaan. Dampak dari tanggung jawab administrasi keuangan umumnya tinggi pada kehadiran kepala keuangan di alat lokal di pemerintahan Aceh Timur. Pengaruh Jabatan Administrator Keuangan terhadap Pengangkatan Direktur Keuangan menunjukkan bahwa variabel bagian kepala keuangan provinsi sebesar 0,248. Ini berarti menghilangkan $\mathrm{Ha}$ dan menghilangkan Ho, bisa dikatakan bahwa pekerjaan direktur keuangan tidak mempengaruhi kinerja administrator keuangan karena tingkat besar lebih menonjol dari 0,05. Dapat dijelaskan bahwa perwakilan yang berada di bawah administrasi keuangan juga memiliki posisi untuk menyelesaikan tugas yang terkait dengan administrasi keuangan.

\section{Kesimpulan dan Saran}

Adapun kesimpulan dari hasil penelitian bahwa tanggung jawab pengawas keuangan dan tugas pengelola keuangan dalam SKPK Pemerintah Aceh Timur secara bersama-sama mempengaruhi keberadaan pejabat eselon IV yang menyelenggarakan tugas administrasi keuangan. Selain itu, tanggung jawab pengawas keuangan secara positif mempengaruhi kepala keuangan, namun pekerjaan direktur keuangan tidak mempengaruhi administrator eksekusi keuangan. 
Sedangkan saran untuk Pemerintah Daerah Aceh Timur agar dapat meningkatkan penyajian SKPK dan memastikan tanggung jawab kerja pengelola keuangan sehingga penyelenggaraan ke daerah dapat berjalan dengan baik. keterusterangan dan keterusterangan teknik melalui sosialisasi sehingga semua direktur keuangan fokus menjalankan sebagai administrator keuangan dengan tepat.

\section{Ucapan Terima Kasih}

Kami sebagai peneliti mengucapkan terima kasih yang sebesar-besarnya kepada Deputi Bidang Penguatan Riset dan Pengembangan Kementerian Riset dan Teknologi/Badan Riset dan Inovasi Nasional, Kementerian Pendidikan dan Kebudayaan, serta LLDIKTI Wilayah XIII Provinsi Aceh sebagai penyandang dana penelitian pada skema Penelitian Dosen Pemula (PDP) tahun 2021, dan tidak lupa pula kepada LPPM Akademi Keuangan Perbankan Nusantara, yang telah ikut menfasilitasi kelancaran proses penelitian ini.

\section{Daftar Pustaka}

Alhayati, F. (2013). Wisuda Periode Maret 2013. Pengaruh Tingkat Hutang (Leverage) Dan Tingkat Kesulitan Keuangan Perusabaan Terbadap Konservatisme Akuntansi (Studi Empiris Pada Perusahaan Yang Terdaftar Di PT BEI).

Alokasi, D., Atas, K., Modal, B., Pemerintah, P., \& Pontoh, W. (2013). Pengaruh Komitmen Organisasi dan Peran Manajer Pengelola Keuangan Daerah terhadap Kinerja Manajerial Satuan Kerja Perangkat Daerah di Kota Manado. Jurnal Accountability, 2(1), 1-211.

Baihaqi. (2012). Pengaruh Komitmen Organisasi dan Peran Manajerial Pengelolaan Keuangan Terhadap Kinerja Manajerial Satuan Kerja Perangkat Daerah. Fakultas Ekonomi Universitas Bengkulu, 1 No 3243-(2007), 243-253.
Diyanto, V., Rasuli, M., \& Octalia, R. (2015). Pengaruh Komitmen Organisasi, Peran Pengelola Keuangan Daerah, Partisipasi Anggaran, dan Akuntabilitas Publik terhadap Kinerja Pimpinan Satuan Kerja Perangkat Daerah Kota Payakumbuh. Jurnal Online Mahasiswa Fakultas Ekonomi Universitas Riau, 2(2), 33994.

Doktor, A., Ekonomi, I., \& Pascasarjana, P. (1945). Musa Djamaludin. 5.

Maria Mega Ayu Novrilia, Nina Widowati, D. H. (2014). Analisis Kinerja Pegawai di Dinas Pengelolaan Keuangan dan Aset Daerah Kota Semarang ( Studi Kasus Bidang Aset Daerah ). Fakultas Ilmu Sosial Dan Ilmu Politik.

Mone.dkk. (2013). Pengaruh Pengelolaan Keuangan Daerah Terhadap Kinerja Ekonomi Daerah di Kabupaten Pangkep. Jurnal Akuntansi, 3(3), 1-17.

Ranty Sapitri. (2016). Pengaruh Komitmen Organisasi Terhadap Kinerja Karyawan Perusahaan Listrik Negara Area Pekanbaru. Jom Fisip, 3(2), 1-15.

Shalahuddin, A. (2018). Pengaruh Kompetensi, Komitmen Organisasional dan Employee Engagement Terhadap Kinerja Pegawai PDAM Tirta Khatulistiwa Pontianak. Jurnal Ekonomi Bisnis Dan Kewirausabaan, 7(3), 202. https://doi.org/10.26418/jebik.v7i3.2687 5

Sukarno, K. W., \& Syaichu, M. (2006). Analisis Faktor-Faktor Yang Mempengaruhi Kinerja. Fakultas Ekonomika Dan Bisnis Universitas Diponegoro, 3(2003), 46-58.

Wulandari, R. (2016). Pengaruh peran pengelola keuangan dan komitmen organisasional serta pemanfaatan sistem informasi keuangan daerah terhadap kinerja manajerial satuan kerja perangkat daerah (studi pada pemerintah kota samarinda). Fakultas Ekonomi Dan Bisnis Universitas Mulawarman. 